\title{
The Dependence of Cocksfoot Productivity of Liming and Nitrogen Application and the Assessment of Qualitative Parameters and Environmental Impact Using Biomass for Biofuels
}

\author{
Gintaras Šiaudinis ${ }^{1}$, Algirdas Jasinskas ${ }^{2, *}$, Danutè Karčauskiene ${ }^{1}$, Egidijus Šarauskis ${ }^{2} \oplus$, \\ Kristina Lekavičiene ${ }^{2}$ and Regina Repšiene் ${ }^{1}$ \\ 1 Vėžaičiai Branch of the Lithuanian Research Centre for Agriculture and Forestry, Gargždu Str. 29, \\ LT-96216 Vėžaičiai, Klaipėda Distr., Lithuania; gintaras.siaudinis@lammc.lt (G.Š.); \\ danute.karcauskiene@lammc.lt (D.K.); regina.repsiene@lammc.lt (R.R.) \\ 2 Agriculture Academy, Institute of Agricultural Engineering and Safety, Vytautas Magnus University, \\ Studentu Str. 15A, LT-53362 Akademija, Kaunas Distr., Lithuania; egidijus.sarauskis@vdu.lt (E.Š.); \\ kristina.lekaviciene@vdu.lt (K.L.) \\ * Correspondence: algirdas.jasinskas@vdu.lt; Tel.: +370-612-04002
}

Received: 8 September 2020; Accepted: 3 October 2020; Published: 5 October 2020

\begin{abstract}
In order to evaluate the liming and nitrogen efficiency of cocksfoot (Dactylisglomerata L.) productivity, a field experiment was performed in Western Lithuania's naturally acidic Retisol area $\left(55^{\circ} 43^{\prime} \mathrm{N}, 21^{\circ} 27^{\prime} \mathrm{E}\right)$. Based on seven years of research data, dry mass (DM) yield (including first and second cuttings) reliably varied depending on the growing year, from 4.57 to $7.34 \mathrm{tha}^{-1}$. The most significant and positive impact on DM yield was obtained by the application of higher liming $\left(6.0 \mathrm{t} \mathrm{ha}^{-1} \mathrm{CaCO}_{3}\right)$ and nitrogen $\left(120 \mathrm{~kg} \mathrm{ha}^{-1}\right)$ rates. Liming utilization efficiency (LUE) was affected by the year of growth (although not always significantly), with a $6.0 \mathrm{tha}^{-1} \mathrm{CaCO}_{3}$ liming rate and nitrogen fertilization. Nitrogen utilization efficiency (NUE) varied depending on the growing year and $\mathrm{N}$ fertilization rate. One of the most effective solutions for improving cocksfoot biomass is to prepare pressed granulated biofuel, which is potentially a good quality raw material for the direct combustion process. The execution and evaluation of technological parameters and properties of produced pellets revealed that cocksfoot pellet humidity reached $10.0 \% \pm 0.6 \%$, whereas pellet density was sufficiently high, and reached $983.8 \pm 22.9 \mathrm{kgm}^{-3} \mathrm{DM}$. The lower calorific value of cocksfoot pellets reached $17.7 \mathrm{MJkg}^{-1}$. Ash content after pellet burning was relatively high, reaching $7.0-7.6 \%$. Pellet ash melting temperatures were sufficiently high, with ash softening temperature (ST) reaching $1065^{\circ} \mathrm{C}$. Determined emissions of harmful gases from the burning of cocksfoot pellets $\left(\mathrm{CO}_{2}, \mathrm{CO}, \mathrm{SO}_{2}\right.$, $\mathrm{NO}_{\mathrm{x}}$ and unburnt hydrocarbons $\mathrm{C}_{\mathrm{x}} \mathrm{H}_{\mathrm{y}}$ ) did not exceed the permissible limits.
\end{abstract}

Keywords: Dactylisglomerata; liming; nitrogen; productivity; LUE; NUE; biomass quality; pellet properties; harmful emissions

\section{Introduction}

The interest in alternative energy has been increasing in many European countries for a few decades. The European Council has set a target, which obliges EU countries to reduce greenhouse emission up to $80-95 \%$ by 2050 . The type of alternative energy and its development in a particular country depends on several factors, i.e., geographical location and economic and political conditions [1]. Concerning different renewable sources, the importance of biomass is steadily increasing in many EU countries [2]. Facing the increase in demand for biomass as a renewable energy source and in order to 
avoid competition with traditional food crops, energy crops should be cultivated in less productive agricultural soils. Special focus should be paid to the species with high biomass yields, low growing costs and good adaptation to local growing conditions [3,4].

Cocksfoot (Dactylisglomerata L.) is a traditional forage grass species in Lithuania and other temperate climate countries $[4,5]$. Recently, livestock production in the country has declined; thus, some fodder grasses (including cocksfoot) could be grown and their biomass might be a suitable material for the biofuel industry [6-8]. As a fodder crop, cocksfoot is highly productive, but because of the high fiber content in its biomass, its feeding value is lower compared to other species. Furthermore, the share of livestock in the agricultural sector has declined recently. Depending on market demand, as an alternative, some tall cereal grasses (particularly cocksfoot) might be grown as monocultures and their biomass used for solid biofuel production. In this respect, less productive, set-aside or degraded soils are more appropriate for non-food crop cultivation [9,10]. For example, Western Lithuania is less favorable for traditional farming, because naturally acidic Retisols prevail there. Liming is a traditional means of improving soil quality and decreasing soil acidity. Another option would be the designation of a share of the agricultural area for energy crop growing.

Although cocksfoot is not demanding to soil conditions, there are few scientific articles that discuss the effect of liming or address the question of how cocksfoot tolerates different levels of soil acidity $($ soil $\mathrm{pH})$ and how it affects its biomass yield [11,12]. Some studies have shown that liming improves the ability of some plant species (particularly perennial grasses) to absorb nitrogen in limed soils [13,14]. However, this topic has not yet been sufficiently investigated. Many authors have conducted research and published data concerning the effect of nitrogen on cocksfoot productivity $[4,5,12,15]$. However, the efficiency of nitrogen fertilizers can vary depending on various factors, especially soil and climatic conditions $[16,17]$.

For an understanding of suitability of a feedstock for energy production, it is important to carry out analysis of the basic composition of the feedstock [18]. This is determined through the weight percentages of chemical elements (carbon, hydrogen, nitrogen, oxygen and sulfur) in the biomass $[19,20]$. Carbon, nitrogen, hydrogen and oxygen are the main components of solid fuels. During the combustion process, carbon and oxygen react in an exothermic reaction by generating $\mathrm{CO}_{2}$ and $\mathrm{H}_{2} \mathrm{O}$ [21]. Fixed carbon represents the quality of carbon trapped in the biomass by the photosynthetic process: a higher content of fixed carbon represents a higher biomass quality, because of its increased heating value [22]. Important properties of biofuels after burning are ash content and ash melting characteristics, because they have a direct impact on the operation of a boiler [23]. The properties of straw depend very much on the location, growing time and weather conditions during cultivation, and on soil quality and fertilization [24]. The melting behavior of ash depends on its mineral composition, and even slight differences in composition can significantly change the characteristics of the melt [23].

Although acidic in nature, the acidity levels of Retisols vary depending on the location. Thus, we aimed to study three areas of different soil $\mathrm{pH}$ levels in order to determine (1) the influence of liming and nitrogen fertilization on cocksfoot productivity, and (2) the efficiency of liming material and nitrogen fertilization. The third part of our work consisted of the determination of the energetic and environmental parameters of cocksfoot pellets, relevant to their preparation and utilization for biofuel purposes. Scientists usually study individual technological variants and stages of work. Such a complex assessment, analyzing not only the cultivation and care of plants, but also the possibility of processing and utilizing them for energy purposes, is a novel area of study, which is relevant for agricultural and energy specialists.

\section{Materials and Methods}

\subsection{Field Experiment}

The field experiment with common cocksfoot (Dactylisglomerata L.) was carried out at the Vèžaičiai Branch of the Lithuanian Research Centre for Agriculture and Forestry (Western Lithuania, $55^{\circ} 43^{\prime} \mathrm{N}$, 
$\left.21^{\circ} 27^{\prime} \mathrm{E}\right)$ during $2010-2016$. The soil of the experimental site was naturally acid $\left(\mathrm{pH}_{\mathrm{KCl}} 4.25-4.85\right)$ moraine loam (BathygleyicDystric GlossicRetisol) (WRB 2014).

The experiment was composed with a two-factor design. The experimental site was divided into three separate plots, differing by their liming rates (not limed, limed with $3.0 \mathrm{tha}^{-1} \mathrm{CaCO}_{3}(0.5$ rate) and limed with $1.0\left(6.0 \mathrm{t} \mathrm{ha}^{-1}\right)$ (1.0rate) (first factor). Three nitrogen rates $\left(0,60\right.$ and $\left.120 \mathrm{~kg} \mathrm{ha}^{-1}\right)$ (second factor) were randomly allocated throughout all three liming plots. The gross area of each plot (treatment) was $20 \mathrm{~m}^{2}$ and the harvested area was $14 \mathrm{~m}^{2}$ (Figure 1).

\begin{tabular}{|c|c|c|c|c|c|c|c|c|}
\hline No & N60 & N120 & No & N60 & N120 & No & N60 & N120 \\
\hline N60 & N120 & N0 & N120 & No & N60 & N60 & N120 & No \\
\hline N120 & No & N60 & N60 & N120 & N0 & N120 & No & N60 \\
\hline \multicolumn{3}{|c|}{ Not limed } & \multicolumn{3}{|c|}{ Limed with 0.5 rate } & \multicolumn{3}{|c|}{ Limed with 1.0 rate } \\
\hline
\end{tabular}

Figure 1. Schematic representation of field experimental scheme, comprisingthree strips differing by liming rates and plots with threedifferent nitrogen rates.

The experimental plots were limed once in 2008, one year before establishing the experiment. Nitrogen fertilizers were applied each year in April. The highest nitrogen rate $\left(120 \mathrm{~kg} \mathrm{ha}^{-1}\right)$ was broadcasted twice - in April (before the beginning of the growing season) and at the beginning of July (after the first grass cutting). The annual rates of phosphorus $\left(\mathrm{P}_{2} \mathrm{O}_{5}\right)$ and potassium $\left(\mathrm{K}_{2} \mathrm{O}\right)$ fertilizers were the same, namely $60 \mathrm{~kg} \mathrm{ha}^{-1}$.

Common cocksfoot (cv. Amba) was sown on 14 July 2009 at a rate of $15 \mathrm{~kg} \mathrm{ha}^{-1}$ viable seeds. In each experimental year, grass harvesting was carried out two times per growing season. Starting from 2010, the first cutting was performed at the full maturity stage. The second cutting (aftermath) was carried out at the end of September. The harvestable area of all the treatments was $14 \mathrm{~m}^{2}$.

Nitrogen utilization efficiency (NUE) was calculated according to the following equation: ((DM yield with applied fertilizer $\mathrm{N}$ rate) - (DM yield in zero- $\mathrm{N})) / \mathrm{N}$ rate, where $\mathrm{N}$ is the amount of $\mathrm{N}$ in $\mathrm{kg} \mathrm{ha}^{-1}$ (according to Gan et al., 2008). Lime utilization efficiency (LUE) was calculated by the similar equation: ((DM yield with lime application) - (DM yield without liming))/L rate ( $\mathrm{t} \mathrm{ha}^{-1} \mathrm{CaCO}_{3}$ rate).

\subsection{Technological Parameters and Their Evaluation}

In 2013, after the first grass cutting, dried samples of cocksfoot were used for pellet production. Before the cocksfoot pellets were produced, their biomass was chopped and milled using a Retsch SM 200 (Retsch, Germany) chaff mill.

For comparison, pellets of Miscanthus (silvergrass) were produced and investigated as a control sample. These plants are widely used in countries south of Lithuania as energy plants.

Then, the milled biomass was granulated using a "Peleciarka" small-capacity granulator (Company POLEXIM, Poland), forming 6-mm-diameter pellets. The following pellet properties were determined: moisture content, ash content and calorific value. Before the milled product entered the granulator, it was mixed thoroughly to achieve homogeneity and moistened if it was too dry for granulation. By the dosage unit the mix was supplied to the press chamber, where it was moved by rollers through the matrix holes and pressed to form pellets of $6 \mathrm{~mm}$ in diameter. 
When the pellets cooled, their biometric and physical-mechanical parameters (dimensions, moisture content, volume and density) were evaluated. The parameters of 10 pellets were determined by measuring their height and diameter (accurate to $0.05 \mathrm{~mm}$ ).

Thepellet moisture content was determined in a laboratory drying chamber oven according to the standard method. The pellet volume was calculated using the pellet size (diameter and length).

Thepellet elemental composition was determined at the Lithuanian Energy Institute (LEI) Thermal Equipment Research and Testing Laboratory in accordance with the following valid Lithuanian and EU standard methodology. The calorific value $\left(\mathrm{KJkg}^{-1}\right)$ of the plant chaff was determined using a C2000 calorimeter (IKA, Germany) and the standard methodology (BS EN 14918:2009).

Characteristics of ash melting temperatures were determined by using high temperature carbolite CAF digital furnace, following the methodology according to the LST CEN/TS 15370-1:2007 standard. Fuel burning efficiency and harmful emissions were evaluated out in the LEI Thermal Equipment Research and Testing Laboratory. Pollutants were measured in a fuel gas analyzer, Datatest 400 CEM, VE7, in the burning process.

Determination of total carbon, hydrogen, nitrogen, sulfur and oxygen was performed according to the requirements of standard EN 15104:2010. Pellet samples $(5 \mathrm{~kg})$ were delivered to the biofuel burning laboratory, where combustion and emissions of harmful substances $\left(\mathrm{CO}, \mathrm{CO}_{2}, \mathrm{NO}_{\mathrm{x}}, \mathrm{C}_{\mathrm{x}} \mathrm{H}_{\mathrm{x}}\right)$ were evaluated. The pellet burning and emission testing period was of 8-10minutes' duration for each sample. The emissions of harmful substances were compared to the combustion of granulated biofuel produced from the other energy plant, Miscanthus.

\subsection{Statistical Analysis}

The data of the dry mass (DM) yield (including the first and second cuttings), nitrogen utilization efficiency (NUE) and LUE (liming utilization efficiency) were statistically processed using analysis of variance (ANOVA) as a three-factorial randomized block variant to determine significant differences between means by using Fisher's protected least significant difference $(p<0.05$ and $p<0.01)$ and least significant difference $\left(L S D_{05}\right.$ and $\left.L S D_{01}\right)$ tests.

\subsection{Meteorological Conditions}

In 2010, wet and cool weather prevailed at the beginning of the growing season. Later, there were two dry periods (in July and mid-August). During both the first and second halves of the growing year, the amount of precipitation was higher than the average annual amount. At the beginning of the growing season in 2011, cool weather prevailed. The weather in the second half of May was drier and warmer than usual for this period. Compared to 2010, the amount of precipitation (especially on the first half of vegetation) was slightly lower. However, the distribution of precipitation during the growing season was almost equal. In 2012, cool and moderately humid weather prevailed for the first half of the growing season. Starting from the beginning of July, warm and moderately humid weather prevailed. Precipitation during the entire growing season was significantly lower compared to the first two experimental years. In 2013, weather temperature in May-August was close to the multi-annual average. A shortage of precipitation occurred during the period of intensive growth-from the second half of May to the second half of June. Overall, the amount of precipitation per growing season was less than the annual average. In 2014, cool and relatively dry weather prevailed until the end of June. After early July, dry and warm weather prevailed. Thus, there was a lack of moisture in the upper soil layer. Abundant rain fell in the second and third ten-day periods of August. In 2015, cool and rainy weather dominated at the first half of the season. Very warm and dry weather settled only in August. Periodically, there was a lack of moisture in the upper soil layer. In 2016, the amount of precipitation increased steadily during the growing season. Monthly temperatures were close to their multiannual values. In that year, growing conditions for perennial grasses were quite favorable. 


\section{Results and Discussion}

\subsection{Dry Mass (DM) Yield, Liming and Nitrogen Utilization Efficiency (LUE and NUE)}

According to the data of theFisher's criterion mean squares, the growing year, liming rate, nitrogen rate, growing year $\times$ liming rate $(p<0.01)$ and liming rate $\times$ nitrogen rate interaction had a significant positive effect on cocksfoot dry mass (DM) yield $(p<0.05)$. Nitrogen utilization efficiency (NUE) was positively influenced by growing year and nitrogen rate $(p<0.01)$. Liming utilization efficiency (LUE) positively correlated with all the following variables: liming rate, nitrogen rate, year of growth $\times$ nitrogen rate $(p<0.01)$ and year of growth, liming rate $\times$ nitrogen rate $(p<0.05)$. However, year of growth $\times$ liming rate had no significant impact on LUE values. The triple interaction (growing year $\times$ liming rate $\times$ nitrogen rate) had a positive effect on the LUE values only (Table 1 ).

Table 1. Fisher criterion's mean squares forcookfoot's dry matter (DM) yield, lime and nitrogen efficiency (LUE, NUE) during 2010-2016 growing seasons.

\begin{tabular}{|c|c|c|c|}
\hline \multirow[b]{2}{*}{ Variables } & \multicolumn{3}{|c|}{ Cocksfoot } \\
\hline & $\begin{array}{l}\text { Dry Mass Yield } \\
(\mathrm{DM})\left(\mathrm{kg} \mathrm{ha}^{-1}\right)\end{array}$ & $\begin{array}{c}\text { NUE } \\
\left(\mathrm{kg} \mathrm{kg}^{-1}\right)\end{array}$ & $\begin{array}{c}\text { LUE } \\
\left(t \mathrm{~kg}^{-1}\right)\end{array}$ \\
\hline Growing year & ** & $* *$ & * \\
\hline Liming rate & ** & $n s$ & $* *$ \\
\hline Nitrogen rate & $* *$ & $* *$ & $* *$ \\
\hline Growing year $\times$ liming rate & $n s$ & $n s$ & * \\
\hline Growing year $\times$ nitrogen rate & ** & $n s$ & ** \\
\hline Liming rate $\times$ nitrogen rate & * & $n s$ & $* *$ \\
\hline Growing year $\times$ liming rate $\times$ nitrogen rate & $n s$ & $n s$ & * \\
\hline
\end{tabular}

${ }^{*}, * *$ significant at $p \leq 0.05$ and $p \leq 0.01$ levels, respectively; $n s-$ not significant.

Dry mass (DM) yield: During the study years (from 2010 to 2016), total DM yield (including the first and second cuts) substantially varied from 4.57 (in 2013) to $7.34 \mathrm{t} \mathrm{ha}^{-1}$ (in 2016) (DM fluctuations between the experimental years constituted $40 \%$ ) (Table 2). Air temperature and especially the amount of precipitation at the intense growth stage of cocksfoot (second half of May and beginning of June) are critical for perennial grass biomass yield. Again, when hot and dry weather prevails, grasses accumulate substantially lesser DM amounts; due to the intensification of plant respiration, a large proportion of organic matter may be decomposed.

In 2013 and especially in 2014, the precipitation amount, average daily temperature and moisture content in the upper soil layer during the May-June period were lower than average multiannual values. As a result, the first cut grass DM yield was quite low, at 2.70 and $2.39 \mathrm{DM} \mathrm{tha}^{-1}$, respectively. However, due to themore favorable moisture regime at the beginning of the first half of the growing season, in the subsequent two years (2015 and 2016), the DM yield increased significantly to 4.38 and $5.46 \mathrm{t} \mathrm{ha}^{-1} \mathrm{DM}$, respectively.

Depending onthe particular year of growth, the share of the second cut grass (aftermath) DM yield varied between $26.8 \%$ and $51.9 \%$. In the first two experimental years, the average second grass yield (aftermath) was high enough and constituted 2.63 and $3.16 \mathrm{t} \mathrm{ha}^{-1}$, respectively. Due to lower soil moisture availability in the second half of the growing season in 2012 and 2015, the second grass DM fell to 1.39 and $1.00 \mathrm{t} \mathrm{ha}^{-1}$, respectively. In 2014, despite relatively low total annual yield $\left(4.98 \mathrm{tha}^{-1}\right)$, the average aftermath yield was $2.58 \mathrm{tha}^{-1}$.

Other studies conducted in the middle area of Lithuania revealed that growing cocksfoot on an Endocalcari-EndohypogleyicCambisol (CMg-p-w-can) (under $\mathrm{pH}$ 5.5-7.0), the average annual DM yield was $6.14 \mathrm{t} \mathrm{ha}^{-1}$ (with $120 \mathrm{~kg} \mathrm{ha}^{-1} \mathrm{~N}$ application) [24]. Meanwhile, other more detailed field experiments revealed that in dependence on growing conditions, the application of $90-180 \mathrm{~kg} \mathrm{ha}^{-1} \mathrm{~N}$ rates caused an increase in the annual cocksfoot DM yield (including three annual cuttings) from 2.80 to $9.20 \mathrm{t} \mathrm{ha}^{-1}$ [4]. 
Table 2. Mean values of dry mass (DM) yield ( $\mathrm{t} \mathrm{ha}^{-1}$ ) (including first and second cuts) depending on growing year, liming and nitrogen fertilization from 2010 to 2016.

\begin{tabular}{|c|c|c|c|}
\hline Variables & First Cutting & Second Cutting & Total DM Yield \\
\hline \multicolumn{4}{|c|}{ Growing Year } \\
\hline 2010 & 3.23 & 2.63 & 5.86 \\
\hline 2011 & 4.04 & 3.16 & 7.22 \\
\hline 2012 & 3.78 & 1.39 & 5.16 \\
\hline 2013 & 2.70 & 1.87 & 4.57 \\
\hline 2014 & 2.39 & 2.58 & 4.98 \\
\hline 2015 & 4.38 & 1.00 & 5.38 \\
\hline 2016 & 5.46 & 1.87 & 7.34 \\
\hline$L S D_{05}$ & 0.26 & 0.42 & 0.36 \\
\hline \multicolumn{4}{|c|}{ Liming } \\
\hline Not limed & 3.47 & 1.92 & 4.94 \\
\hline 0.5 rate & 3.23 & 1.80 & 5.26 \\
\hline 1.0 rate & 4.43 & 2.62 & 6.61 \\
\hline$L S D_{05}$ & 0.24 & 0.26 & 0.32 \\
\hline \multicolumn{4}{|c|}{ Nitrogen fertilization } \\
\hline $0 \mathrm{~kg} \mathrm{ha}^{-1}$ & 2.28 & 1.36 & 3.82 \\
\hline $60 \mathrm{~kg} \mathrm{ha}^{-1}$ & 4.14 & 1.52 & 5.40 \\
\hline $120 \mathrm{~kg} \mathrm{ha}^{-1}$ & 4.72 & 3.45 & 7.59 \\
\hline$L S D_{05}$ & 0.24 & 0.26 & 0.32 \\
\hline
\end{tabular}

The amount of precipitation and thus soil moisture content is an important biotic factor affecting grass productivity. The first cut DM yield strongly and positively correlated with the amount of precipitation in April-June, at 0.78. The correlation between the second cut DM yield and the amount of precipitation in April-June was average, at 0.50 . The correlation between the average daily temperature and DM yield was weak.

A higher liming rate $\left(6.0 \mathrm{tha}^{-1} \mathrm{CaCO}_{3}\right)$ had a positive effect on cocksfoot DM yield. Compared to the control (without liming), the average DM yield increased from 3.47 to $4.43 \mathrm{tha}^{-1}$ (or by $27 \%$ ). Generally, cocksfoot is considered to beless susceptible to soil acidity than other grasses. Despite this, our results, as well as the data of other authors, suggest that soil liming has a positive effect on cocksfoot productivity [11].

In comparison with the control treatment, the application of both $\mathrm{N}$ rates $\left(60\right.$ and $\left.120 \mathrm{~kg} \mathrm{ha}^{-1}\right)$ had a positive and significant effect on DM yield (including the first and second cuts); on average, DM yield increased by $52 \%$ and $227 \%$, respectively. Only the use of a $120 \mathrm{~kg} \mathrm{ha}^{-1} \mathrm{~N}$ rate had a positive impact on the second grass DM yield.

Liming utilization efficiency (LUE): As mentioned, soil liming was performed one year before establishing the experiment. A positive effect was observed during the first and second harvest years (in 2010 and 2011). Having applied 1 ton of $\mathrm{CaCO}_{3}, \mathrm{LUE}$ values increased by 156 and 339, respectively (Figure 2). During the next three successive years of growth (2012, 2013 and 2014), the impact of liming was not observed; thus, there was no substantial effect of liming on cocksfoot productivity. The effect of liming gradually declined in subsequent years of the research. Prior to establishing the experiment, soil $\mathrm{pH}_{\mathrm{KCl}}$ varied from 4.25 to 4.85 . Here it is important to note that three years after the liming had been performed, soil $\mathrm{pH}$ reached 5.5-5.7. Since then, soil acidity decreased to its initial level of $\mathrm{pH}_{\mathrm{KCl}}$ 4.65-4.85 (in 2014-2016). The variations of soil qualitative parameters per experimental period will be presented in a separate article.The positive liming effect was observed again in the last two experimental years-LUE values increased by 219 and $123 \mathrm{kgha}^{-1}$, respectively.

It is likely that even if soil $\mathrm{pH}$ returns to its initial acidity level, the positive effect of liming (due to higher organic matter content and higher microbial activity) remains for several years ahead. Other authors also point out that liming has a long-term impact on both soil and crop productivity $[25,26]$. 


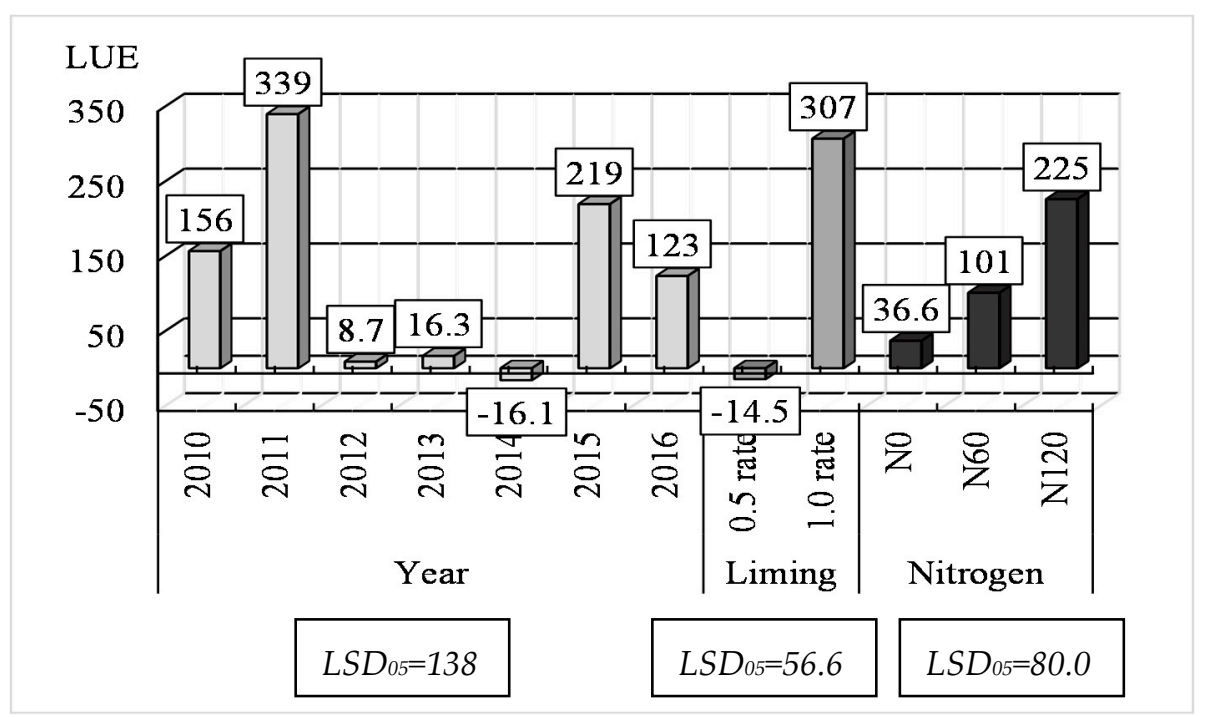

Figure 2. Liming utilization efficiency (LUE) mean values depending on growing year, liming and nitrogen fertilization from 2010 to 2016.

A lower liming rate ( 0.5 rate) had no significant impact on dry mass yield. LUE increased with the application of a 1.0 lime rate, up to 307 on average. Nitrogen fertilizers had a positive impact on LUE. The application of $120 \mathrm{~kg} \mathrm{ha}^{-1} \mathrm{~N}$ rate had a greatest impact on LUE, at 225, on average. This means that liming was more efficient in the plots fertilized with nitrogen fertilizers (particularly $120 \mathrm{~kg} \mathrm{ha}^{-1} \mathrm{~N}$ rate application).

Other authors have described the positive interaction between liming and nitrogen. By increasing $\mathrm{Ca}$ availability, plants are enabled to absorb higher $\mathrm{N}$ amounts and increase plant yields (Bailey, 1995).

Nitrogen utilization efficiency (NUE) varieddepending on the year of growth, although the variations between the values were not always statistically significant (Figure 3). The highest nitrogen efficiency (NUE) was attained in 2011, at 40.7 (i.e., $1 \mathrm{~kg}$ of $\mathrm{N}$ caused the increase of DM yield by $40.7 \mathrm{~kg}$ $\mathrm{ha}^{-1}$ ). Similar NUE values were observed in the following two years. Since 2016, the NUE rate has been declining for three consecutive years.

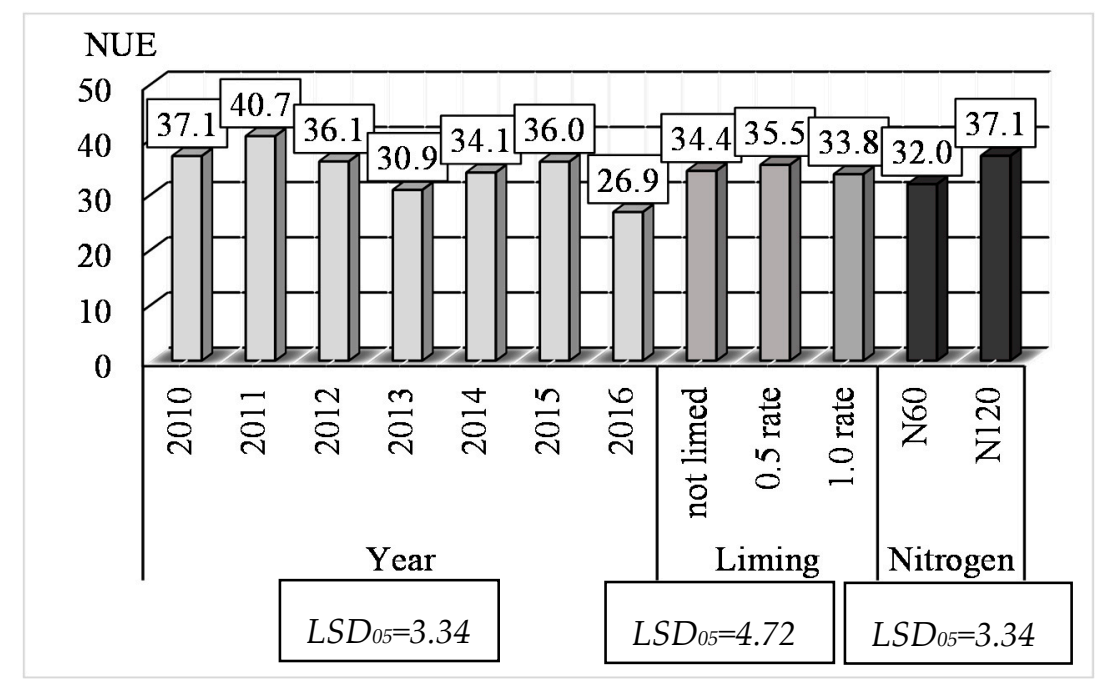

Figure 3. Nitrogen utilization efficiency (NUE) mean values depending on growing year, liming and nitrogen fertilization from 2010 to 2016. 
However, NUE sharply decreased in 2016, up to 26.91, despite the highest DM yield being estimated in that particular growing season. This means that due to favorable growing conditions during 2016, cocksfoot DM yields were high in both nitrogen-free plots and in plots where nitrogen fertilizers were applied. Nitrogen fertilization has a crucial impact on crop productivity. In our case, since the influence of nitrogen fertilizers on DM yield varied significantly from year to year, there was thus no significant mutual correlation between DM yield and NUE during the seven experimental years.

Liming had no significant effect on NUE. Contrarily, both nitrogen rates $\left(60\right.$ and $\left.120 \mathrm{~kg} \mathrm{ha}^{-1}\right)$ had a significant and positive effect on NUE-32.0 and 37.1, respectively (at the $95 \%$ significance level).

\subsection{Energy and Environmental Evaluation of Cocksfoot Plant Pellets}

Qualitative parameters of pellets: The investigated plant pellets were measured (length and diameter) and weighed. The volumes and densities and their square errors were then calculated. The obtained results are presented in Table 3. After the analysis of biometric properties of cocksfoot and the control sample-Miscanthus plant-granules by measuring and weighing, it was found that the granules pressed with a horizontal matrix were of sufficiently high quality.

Table 3. Biometric andqualitative parameters of pellets.

\begin{tabular}{lccccc}
\hline \multirow{2}{*}{ Plant Species } & \multicolumn{5}{c}{ Parameters of Pellets } \\
\cline { 2 - 6 } & $\begin{array}{c}\text { Diameter, } \\
\mathbf{m m}\end{array}$ & $\begin{array}{c}\text { Length, } \\
\mathbf{m m}\end{array}$ & $\begin{array}{c}\text { Volume, } \\
\mathbf{m}^{\mathbf{3}}\end{array}$ & $\begin{array}{c}\text { Mass, } \\
\mathbf{g}\end{array}$ & $\begin{array}{c}\text { Density, } \\
\mathbf{k g ~ m}^{-3}\end{array}$ \\
\hline Cocksfoot & $6.14 \pm 0.04$ & $25.71 \pm 1.39$ & $(7.59 \pm 0.42) \cdot 10^{-7}$ & $0.85 \pm 0.14$ & $\begin{array}{c}1093.5 \pm 122.9 \\
983.8 \pm 122.9 \mathrm{DM} \\
\text { Miscanthus }\end{array}$ \\
& $6.39 \pm 0.19$ & $24.90 \pm 1.41$ & $(7.96 \pm 0.77) \cdot 10^{-7}$ & $0.57 \pm 0.07$ & $\begin{array}{c}713.5 \pm 67.1 \\
653.6 \pm 67.1 \mathrm{DM}\end{array}$ \\
\hline
\end{tabular}

Based on the data analysis presented in Table 3, it can be observed that the density of Miscanthus plant pellets was low, and reached only $653.6 \pm 67.1 \mathrm{kgm}^{-3} \mathrm{DM}$. The granules of sufficiently high density were produced from cocksfoot plants, $983.8 \pm 122.9 \mathrm{kgm}^{-3} \mathrm{DM}$. Based on the research results, it can be stated that although granule densities of the investigated plants differ, they satisfy the requirements for storage, transportation and burning of pressed biofuel.

Physical and thermal properties of pellets:Results of research into the physical properties of the investigated cocksfoot and Miscanthus plant pellets are presented in Table 4. These results show that the determined pellet moisture content ranged from $8.4 \%$ to $10.0 \%$. The ash content was sufficiently high and varied from $7.6 \%$ (cocksfoot) to $8.8 \%$ (Miscanthus). The lower calorific value was very similar and varied from 17.7 to $17.8 \mathrm{MJkg}^{-1} \mathrm{DM}$.

Table 4. Plant pellet moisture content, density, ash content and calorific value.

\begin{tabular}{lcccc}
\hline Plant Species & $\begin{array}{c}\text { Moisture } \\
\text { Content, } \%\end{array}$ & $\begin{array}{c}\text { Density, } \\
\mathbf{K g m}^{-3} \text { (DM) }\end{array}$ & $\begin{array}{c}\text { Ash Content, } \\
\text { \% }\end{array}$ & $\begin{array}{c}\text { Lower Calorific Value, } \\
\mathbf{M J k g}^{-1} \text { (DM) }\end{array}$ \\
\hline Cocksfoot & 10.0 & $983.8 \pm 122.9$ & 7.6 & 17.7 \\
Miscanthus & 8.4 & $653.6 \pm 67.1$ & 8.8 & 17.8 \\
\hline
\end{tabular}

The moisture content is a very important factor that determines the net energy content of biomass material and how it influences the calorific value, combustion efficiency and combustion temperature $[27,28]$. The quality of any biomass or fuel can be observed through the amount of heat energy generated from a fuel unit mass [29].

Other researchers have studied the properties of another plant, fibrous hemp. The calorific value of this plant was low and reached $15.03-16.14 \mathrm{MJkg}^{-1}$. Ash content was very similar to wood ash content and varied from $1.5 \%$ to $2.7 \%$. The beginning of ash deformation (melting) in the samples 
from the year 2009 was $710^{\circ} \mathrm{C}-850{ }^{\circ} \mathrm{C}$ [30]. A. Kakitisand colleagues investigated the properties of briquettes of Bialobrzeski, Futura 75 and Santhica 27 hemp. Their density was high, reaching $1185 \mathrm{kgm}^{-3}$ $\mathrm{DM}$, and their breaking strength varied from 101.3 to $122.4 \mathrm{Nmm}^{-1}$ [31].

Elemental composition of granules. The elemental composition of granules is an important characteristic, as it is used to determine the quality of granules. For example, the amount of nitrogen for wood pellets is $0.3 \%$ andsulfur content is $0.04-0.08 \%$ [32]. Elemental compositions of the investigated plants-total quantities of carbon, hydrogen, nitrogen, sulfur and oxygen-were determined according to the requirements of the Lithuanian Energy Institute standards. Results are presented in Table 5.

Table 5. Elemental composition of plant pellets.

\begin{tabular}{lcccc}
\hline \multirow{2}{*}{ Chemical Content } & \multicolumn{2}{c}{ Cocksfoot (N0) } & \multicolumn{2}{c}{ Miscanthus } \\
\cline { 2 - 5 } & Values & Deviation, $\mathbf{\pm \%}$ & Values & Deviation, $\mathbf{\pm} \%$ \\
\hline C (carbon), \% & 45.44 & 1.41 & 46.22 & 1.18 \\
H (hydrogen), \% & 5.54 & 0.47 & 5.37 & 0.45 \\
N (nitrogen), \% & 1.39 & 0.33 & 0.90 & 0.32 \\
S (sulphur), \% & 0.21 & 0.27 & 0.11 & 0.27 \\
O (oxygen), \% & 39.77 & - & 38.57 & - \\
Ash content, \% & 7.65 & 0.25 & 8.84 & 0.90 \\
\hline
\end{tabular}

The composition of the determined chemical elements of cocksfoot and Miscanthus plants ranged within these close limits: carbon, $45.4-46.2 \%$; hydrogen, $5.4-5.5 \%$; nitrogen, $0.9-1.4 \%$; sulfur, $0.1-0.2 \%$ and oxygen, 38.6-39.8\%.

Ash properties and melting temperature. Cocksfoot and Miscanthus plant pellet properties were also determined after burning, in terms of ash content and ash melting characteristics. These properties are very important for burning quality and have a direct impact on the function and working parts of boilers. These properties can greatly depend on the type or sort of plant.

It was mentioned above (see Table 3), that the determined ash content of both plants was high, with the ash content of the cocksfoot pellet reaching $7.6 \%$ and that of Miscanthus reaching $8.8 \%$.

The determined ash melting temperatures of plant pellets are presented in Table 6 . It should be noted that an important parameter, the ash softening temperature (ST), of cocksfoot pellets was very high, reaching $1065^{\circ} \mathrm{C}$, and the ST temperature of Miscanthus pellet was lower $\left(923^{\circ} \mathrm{C}\right)$, but hemisphere (HT) and melting point (FT) temperatures were very high, at $1254^{\circ} \mathrm{C}$ and $1286^{\circ} \mathrm{C}$ (Table 6). After the analysis of these research results, it can be stated that they are very similar, especially those for cocksfoot pellets, if compared with sawdust pellets of pine, (with ST of $1180^{\circ} \mathrm{C}$, HT of $1200^{\circ} \mathrm{C}$ and FT of $1225^{\circ} \mathrm{C}$ [23].

Table 6. Ash melting temperatures after burning of plant pellets.

\begin{tabular}{lcc}
\hline \multirow{2}{*}{ Parameter } & \multicolumn{2}{c}{ Value of Temperatures, ${ }^{\circ} \mathbf{C}$} \\
\cline { 2 - 3 } & Cocksfoot & Miscanthus \\
\hline IT & 1065 & 877 \\
ST & 1128 & 923 \\
HT & 1186 & 1254 \\
FT & 1206 & 1286 \\
\hline
\end{tabular}

Furthermore, D. Čepauskiene and N. Pedišius investigated reed canary grass and wheat straw with $1 \%$ kaolin additive. The results were as follows: ST $-1000^{\circ} \mathrm{C}, \mathrm{DT}-1200^{\circ} \mathrm{C}, \mathrm{HT}-1250^{\circ} \mathrm{C}$ and FT $-1270{ }^{\circ} \mathrm{C}$ for reed canary grass, and ST $-870{ }^{\circ} \mathrm{C}, \mathrm{DT}-950^{\circ} \mathrm{C}, \mathrm{HT}-1180^{\circ} \mathrm{C}$ and FT $-1250{ }^{\circ} \mathrm{C}$ for wheat straw [32].

It can be stated that cocksfoot and Miscanthus plants are suitable for the production of pressed biofuel, since the calorific value is close to the calorific value of herbaceous and woody plant pellets, 
and moisture content meets the raised requirements. Only the ash content of these plants is more than four times higher than that of wood pellets, however, there is the possibility to using this ash for plant fertilization.

The conducted investigations indicate that the biomass of cocksfoot and Miscanthus plants is potentially a good quality raw material for the direct combustion process, and that these plants can compete with wood, straw or herbaceous plant material.

Harmful emissions $\left(\mathrm{CO}_{2}, \mathrm{CO}, \mathrm{NO}_{\mathrm{x}}\right.$ and $\left.\mathrm{C}_{\mathrm{x}} \mathrm{H}_{\mathrm{y}}\right)$ were estimated by burning cocksfoot and Miscanthus plant pellets in the laboratories of the Lithuanian Energy Institute. The limit values of emitted pollutants from fuel-burning devices in Lithuania are regulated by the norms of emitted pollutants from fuel-burning devices, as confirmed by the Minister of Environment of the Republic of Lithuania (LAND 43-2010) [33].

In boilers heated with solid biofuel, the fuel burning and concentration of emitted pollutants depend on the type of fuel, its quality and form. These fuel parameters are very important when making projections for new fuel-supply burning devices. To investigate the influence of these parameters on pollutant formation, the analysis of a low-power $(5 \mathrm{~kW})$ solid fuel boiler was performed. Pollutants gathered during burning were measured using product analyzers: a Datatest 400CEM and analyzer VE7.

The evaluated harmful gas emissions $\left(\mathrm{CO}_{2}, \mathrm{CO}, \mathrm{NO}_{\mathrm{x}}\right.$ and $\left.\mathrm{C}_{\mathrm{x}} \mathrm{H}_{\mathrm{y}}\right)$ obtained by burning granules are presented in Table 7. The results of these studies show that the combustion process is slowed down when the loaded portion of the investigated plant pellets finishes burning (when the burning intensity decreases), and the emissions of all harmful combustion gases also have a tendency to decrease.

Table 7. Harmful emissions by burning plant granules.

\begin{tabular}{ccccccc}
\hline $\begin{array}{c}\text { Plant } \\
\text { Species }\end{array}$ & $\begin{array}{c}\text { Moisture } \\
\text { Content, \% }\end{array}$ & $\begin{array}{c}\text { Smoke } \\
\text { Temperature, }\end{array}{ }^{\circ} \mathbf{C}$ & $\begin{array}{c}\mathrm{CO}_{\mathbf{2}} \\
\%\end{array}$ & $\begin{array}{c}\mathbf{C O} \\
\mathbf{p p m}\end{array}$ & $\begin{array}{c}\mathbf{N O}_{\mathbf{x}} \\
\mathbf{p p m}\end{array}$ & $\begin{array}{c}\mathrm{C}_{\mathbf{x}} \mathrm{H}_{\mathbf{y}} \\
\mathbf{p p m}\end{array}$ \\
\hline Cocksfoot & 10.0 & 216.2 & 6.0 & 1034.6 & 205.1 & 49.0 \\
Miscanthus & 8.4 & 193.4 & 5.2 & 2294.7 & 216.1 & 61.0 \\
\hline
\end{tabular}

It was estimated that low carbon dioxide $\left(\mathrm{CO}_{2}\right)$ emissions were recorded by burning cocksfoot and Miscanthus plant pellets. They varied from $5.2 \%$ to $6.0 \%$. A sufficiently low carbon monoxide (CO) concentration was detected while burning cocksfoot plant pellets. It reached $1034.6 \mathrm{ppm}$, but when burning Miscanthus pellets, it was about 2.2 times higher.

The emissions of detected nitrogen oxides $\left(\mathrm{NO}_{\mathrm{x}}\right)$ indicate that they do not exceed the permissible limits.They were found to be slightly different, ranging from $205.1 \mathrm{ppm}$ (cocksfoot pellets) to $216.1 \mathrm{ppm}$ (Miscanthus pellets). The emissions of unburned hydrocarbons $\left(\mathrm{C}_{\mathrm{x}} \mathrm{H}_{\mathrm{y}}\right)$ were sufficiently low, reaching 49 ppm (cocksfoot pellets) and 61 ppm (Miscanthus pellets).

Summarizing the results of the emissions analysis, it can be stated that after burning of cocksfoot and Miscanthus plant pellets, harmful emissions did not exceed the permissible values, so burning of these pellets may be recommended in domestic boilers.

For comparison, other researchers also investigated the burning efficiency and harmful emissions by burning various sorts of non-traditional energy plant pellets. Giant knotweed pellets were investigated, and $\mathrm{CO}$ and $\mathrm{NO}_{\mathrm{x}}$ emissions were determined. In that case the $\mathrm{CO}$ concentration was $928.9 \mathrm{mgm}^{-3}$ and the $\mathrm{NO}_{\mathrm{x}}$ concentration reached $297.0 \mathrm{mgm}^{-3}$ [34].

\section{Conclusions}

In Retisol, liming remains a traditional means of controlling the soil acidity level. Thus, despite the fact that cocksfoot is adapted to grow well under various soil $\mathrm{pH}$ levels, liming of Retisols and thus the reduction of soil acidity had a positive and significant impact on its biomass productivity. Nevertheless, the greatest impact on cocksfoot productivity (or DM yield) was achieved by the application of annual $120 \mathrm{~kg} \mathrm{ha}^{-1}$ nitrogen rate $\left(60 \mathrm{~kg} \mathrm{ha}^{-1}\right.$ in spring and $60 \mathrm{~kg} \mathrm{ha}^{-1}$ after the first grass 
cutting), in combination with annual $60 \mathrm{~kg} \mathrm{ha}^{-1} \mathrm{P}_{2} \mathrm{O}_{5}$ and $\mathrm{K}_{2} \mathrm{O}$ fertilization rates. At a certain level, we noticed a positive interaction between liming and nitrogen fertilization. As a result of liming, soil physical properties, microbial activity, as well as humus content in upper soil layer were observed to increase (these data will be presented in a separate article). Cocksfoot, as a tall perennial energy crop, has goodadaptability to different soil conditions and might be grown without reseeding for many years. As a fodder crop, cocksfoot is highly productive, but because of the high fiber content in its biomass, its feeding value is lower compared to other species. However, the share of livestock in the agricultural sector has declined recently. Depending on market demand, as an alternative, some tall cereal grasses (particularly cocksfoot) might be grown as monocultures and their biomass may be used for solid biofuel production.

After the evaluation of cocksfoot and Miscanthus plant suitability for biofuel, it can be statedthat one of the most effective solutions is to prepare pressed granulated biofuel. The biofuel is potentially a good quality raw material for the direct combustion process. The combustion of such pressed biofuel produces high-quality and efficient combustion and minimal harmful emissions to the environment.

The heating efficiency of pellet boilers depends very much on the quality of the pellets and the operating characteristics of the boiler, so it is important to produce pellets of the highest possible quality. The fact that pellet boilers use fully automated pellet supply and combustion regimes also plays an important role in boiler efficiency, which ensures high-quality and complete combustion of biofuels such as cocksfoot and Miscanthus plant pellets.

Overall, the cultivation of local energy crop species and the utilization of their biomass as biofuel may be a choice for some farmers whose agricultural land is of low productivity (high soil acidity) and for whom the growing of traditional agricultural crops is often unprofitable. Moreover, it would help to solve the issue of labor markets in rural areas, as well as accelerating the related industries, i.e., biofuel manufacturing, distribution and consumer markets.

Author Contributions: Conceptualization, G.Š., A.J. and D.K.; methodology, G.Š., A.J. and R.R.; software, D.K. and E.Š.; investigation, G.Š., A.J., K.L. and R.R.; resources, D.K. and E.Š.; data curation, G.Š. and A.J.; writing-original draft preparation, G.Š. and A.J.; writing-review and editing, G.Š., A.J., D.K. and K.L.; supervision, G.Š. and A.J.; funding acquisition, D.K. and E.S. All authors have read and agreed to the published version of the manuscript.

Funding: This research received no external funding.

Acknowledgments: The study was conducted in compliance with the long-term program "Plant biopotential and quality for multifunctional practice".

Conflicts of Interest: The authors declare no conflict of interest.

\section{References}

1. Bentsen, N.S.; Felby, C. Biomass for energy in the European Union-a review of bioenergy resource assessments. Biotechnol. Biofuels 2012, 5, 25. [CrossRef] [PubMed]

2. Pedroli, B.; Elbersen, B.; Frederiksen, P.; Grandin, U.; Heikkilä, R.; Krogh, P.H.; Izakovicova, Z.; Johansen, A.; Meiresonne, L.; Spijker, J. Is energy cropping in Europe compatible with biodiversity?-Opportunities and threats to biodiversity from land-based production of biomass for bioenergy purposes. Biomass Bioenergy. 2013, 55, 73-86. [CrossRef]

3. McKendry, P. Energy production from biomass (part 1): Overview of biomass. Bioresour. Technol. 2002, 83, 37-46. [CrossRef]

4. Tilvikiene, V.; Kadziuliene, Z.; Dabkevicius, Z.; Venslauskas, K.; Navickas, K. Feasibility of tall fescue. cocksfoot and reed canary grass for anaerobic digestion: Analysis of productivity and energy potential. Ind. Crops Prod. 2016, 84, 87-96. [CrossRef]

5. Tilvikienè, V.; Venslauskas, K.; Navickas, K.; Župerka, V.; Dabkevičius, Z.; Kadžiulienė, Ž. The biomass and biogas productivity of perennial grasses. Zemdirbyste 2012, 99, 17-22.

6. Pocienè, L.; Šarūnaitè, L.; Tilvikienè, V.; Šlepetys, J.; Kadžiulienė, Ž. The yield and composition of reed canary grass biomass as raw material for combustion. Biologija 2013, 59, 195-200. [CrossRef] 
7. Kazlauskaite-Jadzevice, A.; Marcinkonis, S.; Baksiene, E. Energy value of biomass produced on various land uses in a sandy loam Haplic Luvisol. Zemdirbyste 2016, 103, 143-150. [CrossRef]

8. Solati, Z.; Manevski, K.; Jørgensen, U.; Labouriau, R.; Shahbazi, S.; Lærke, P.E. Crude protein yield and theoretical extractable true protein of potential biorefinery feedstocks. Ind. Crops Prod. 2018, 115, 214-226. [CrossRef]

9. Valentine, J.; Clifton-Brown, J.; Hastings, A.; Robson, P.; Allison, G.; Smith, P. Food vs. fuel: The use of land for lignocellulosic 'next generation' energy crops that minimize competition with primary food production. Glob. Change Biol. Bioenergy 2012, 4, 1-19. [CrossRef]

10. Searchinger, T.; Heimlich, R. Avoiding Bioenergy Competition for Food Crops and Land; World Resources Institute: Washington, DC, USA, 2015; pp. 1-44.

11. Poozesh, V.; Castillon, P.; Cruz, P.; Bertoni, G. Re-evaluation of the liming-fertilization interaction in grasslands on poor and acid soils. Grass Forage Sci. 2010, 65, 260-272. [CrossRef]

12. Williams, S. Nitrogen and Water Uptake of Lucerne and Cocksfoot-Perennial Lupine Pastures under Dryland Conditions. Ph.D. Thesis, Lincoln University, Christchurch, New Zealand, 2015; p. 45.

13. Aulakh, M.S.; Malhi, S.S. Interactions of nitrogen with other nutrients and water: Effect on crop yield and quality, nutrient use efficiency, carbon sequestration and environmental pollution. Adv. Agron. 2005, 86, 341-409.

14. Abalos, D.; Jeffery, S.; Sanz-Cobena, A.; Guardia, G.; Vallejo, A. Meta-analysis of the effect of urease and nitrification inhibitors on crop productivity and nitrogen use efficiency. Agric Ecosyst Environ. 2014, 189, 136-144. [CrossRef]

15. Bailey, J.S. Liming and nitrogen efficiency: Some effects of increased calcium supply and increased soil $\mathrm{pH}$ on nitrogen recovery by perennial ryegrass. Commun. Soil Sci. Plant Anal. 1995, 26, 1233-1246. [CrossRef]

16. Sun, X.; Luo, N.; Longhurst, B.; Luo, J. Fertiliser nitrogen and factors affecting pasture responses. Open Agric. J. 2008, 2, 35-42. [CrossRef]

17. Sulaiman, S.A.; Bamufleh, H.S.; Tamili, S.N.A.; Inayat, M.; Naz, M.Y. Characterization of date palm fronds as a fuel for energy production. Bull. Chem. Soc. Ethiop. 2016, 30, 465-472. [CrossRef]

18. Ren, T.; Enchen, J.; Yan, S.; Xiwei, X.; Shu, R. The Pelletization and Combustion Properties of Terrified Camelia Shell via Dry and Hydrothermal Torrefaction: A Comparative Evaluation. Bioresour. Technol. 2018, 264, 78-89.

19. Yin, C.Y. Prediction of higher heating values of biomass from proximate and ultimate analyses. Fuel 2011, 90, 1128-1132. [CrossRef]

20. Alvarez-Alvarez, P.; Pizarro, C.; Barrio-Anta, M.; Camara-Obregon, A.; Bueno, J.M.L.; Alvarez, A.; Gutierrez, I.; Burslem, D.F. Evaluation of tree species for biomass energy production in northwest Spain. Forests 2018, 9, 160. [CrossRef]

21. Obernberger, I.; Thek, G. Physical characterisation and chemical composition of densified biomass fuels with regard their combustion. Biomass Bioenergy 2004, 27, 653-669. [CrossRef]

22. Alakangas, E. Properties of Fuels Used in Finland; VTT: Espoo, Finland, 2000; pp. 172-189.

23. Vares, V.; Kask, U.; Muiste, P.; Pihu, T.; Soosaar, S. Manual for Biofuel Users; Tallinn University of Technology manual; Tallinn University: Tallinn, Estonia, 2007; p. 178.

24. Slepetys, J.; Kadziuliene, Z.; Sarunaite, L.; Tilvikiene, V.; Kryzeviciene, A. Biomass potential of plants grown for bioenergy production. In Proceedings of the International Scientific Conference "Renewable Energy and Energy Efficiency", Jelgava, Latvia, 28-30 May 2012; pp. 66-72.

25. Davies, D.A. Long-term effects of improvement methods on Molinia caerulea dominant rough grazing on wet hill land. 1. Pasture production, quality and botanical composition. J. Agric. Sci. 1987, 109, 231-241. [CrossRef]

26. Holland, J.E.; Bennett, A.E.; Newton, A.C.; White, P.J.; McKenzie, B.M.; George, T.S.; Pakeman, R.J.; Bailey, J.S.; Fornara, D.A.; Hayes, R.C. Liming impacts on soils. Crops and biodiversity in the UK: A review. Sci. Total Environ. 2018, 610, 316-332. [CrossRef] [PubMed]

27. Jasinskas, A.; Šiaudinis, G.; Martinkus, M.; Karčiauskienė, D.; Repšienė, R.; Pedišius, N.; Vonžodas, T. Evaluation of Common Osier (Salix viminalis L.) and Black Poplar (Populusnigra L.) Biomass Productivity and Determination of Chemical and Energetic Properties of Chopped Plants Produced for Biofuel. Baltic For. 2017, 23, 666-672. 
28. Parmar, K. Biomass-An overview on composition characteristics and properties. IRA Int. J. Appl. Sci. 2017, 7, 42-51. [CrossRef]

29. Kumar, R.; Pandey, K.K.; Chandrashekar, N.; Mochan, S. Effect of tree-age on calorific value and other fuel properties of Eucalyptus hybrid. J. For. Res. 2010, 21, 514-516. [CrossRef]

30. Poisa, L.; Adamovics, A. Evaluate of hemp (Cannabis sativa L.) quality parameters for bioenergy production. Proceedings of the 10th International Scientific and Practical Conference Environment. Technol. Resour. 2011, 26, 358-362.

31. Kakitis, A.; Nulle, I.; Ancans, D. Mechanical properties of composite biomass briquettes. Proceedings of the 10th International Scientific and Practical Conference Environment. Technol. Resour. 2011, 1, 175-183.

32. Čepauskienè, D.; Pedišius, N. Investigation of the effect of kaolin additive and different ashing temperatures of agro mass. In Proceedings of the Conference CYSENI, Kaunas, Lithuania, 23-24 May 2018; pp. 35-39.

33. Jasinskas, A.; Sakalauskas, A.; Šarauskis, E.; Vaiciukevičius, E.; Kalinauskaitè, S. Investigation of boiler efficiency and harmful emissions while burning of plant biomass briquettes. J. Food Agric. Environ. 2012, 10, 1124-1127.

34. Malatak, J.; Passian, L. Heat-emission analysis of small combustion equipments for biomass. J. Agric. Eng. Res. 2011, 57, 37-50. [CrossRef]

(C) 2020 by the authors. Licensee MDPI, Basel, Switzerland. This article is an open access article distributed under the terms and conditions of the Creative Commons Attribution (CC BY) license (http://creativecommons.org/licenses/by/4.0/). 